\title{
Falaşalar veya Etiyopya Yahudileri
}

Dursun Ali AYKIT*

\section{Falashas or Ethiopian Jews}

Citation/(C: Aykıt, Dursun Ali, (2014). Falashas or Ethiopian Jews, Milel ve Nihal, 11 (2), 35-60.

Abstract: There are different names which have been given to Ethiopian Jews, such as Falasha, Kayla, Beta Israel, and Buda. At the same time, there are academically discussions about their origins. In this article, we will mention the theories about Falashas' origin and their history. Then we will give some information about their beliefs, which differ them from other Jewish groups.

Key Words: Falasha, Ethiopia, Beta Israel, Aliyah, Ge'ez, Kebra Nagast, Operation Moses and Solomon.

Atıf/@: Aykıt, Dursun Ali, (2014). Falaşalar veya Etiyopya Yahudileri, Milel ve Nihal, 11 (2), 35-60.

Öz: Etiyopyalı Yahudilere, Falaşa, Kayla, Beta Israel ve Buda gibi farklı isimler verilmektedir. Aynı zamanda onların kökenleri ile ilgili akademik tartışmalar bulunmaktadır. Bu makalede Falaşa'ların kökeni ile ilgili teorilere ve tarihlerine değineceğiz. Ardından onları diğer Yahudi gruplardan ayıran inançları hakkında bilgiler sunacağız.

Anahtar Kelimeler: Falaşa, Etiyopya, Beta Israel, Aliya, Ge'ez, Kebra Nagast, Musa ve Süleyman Operasyonu.

* Doç. Dr., Cumhuriyet Üniversitesi, İlahiyat Fakültesi, Dinler Tarihi Anabilim Dalı [aykit@yahoo.com] 


\section{Giriș: İsimlendirme}

Etiyopya'da yaşayan ve özellikle XX. Yüzyılda büyük bir kısmı İsrail'e göçmüş olan Yahudilere, farklı isimler verilmektedir. Bunlardan en yaygın olanı Falaşa' dır. Ge'ez dilinde 'kendi aslî mekânından başka bir yere sürgün giden' anlamındaki Falaşa kelimesi, bu bağlamda daha çok XIV-XVI. yüzyılda yaşadıkları bir tecrübeden dolayı bunlara verilmiş bir isim olarak kullanılmaktadır.

Beta İsrael şeklindeki bir diğer tanımlama da Etiyopya' da yaşayan Yahudilere verilen adlandırmalardan biridir. İsrail'in evi anlamina gelen bu terimi, kendileri daha çok tercih etmektedir. Fakat burada en önemli problem, 'İsrail'in evi' gibi bir isimlendirmeyi aynı zamanda kendi köklerini Süleyman'ın soyundan geldiğini ileri süren Hiristiyan Etiyopyalıların da kullanmasıdır.

Bu gruba, Etiyopya Yahudileri de denilmektedir. Fakat özellikle 1970 ve 1990'lı yıllar arasındaki aliya operasyonları ile artık birçok Etiyopya kökenli Yahudi, İsrail' de yaşamaktadır. ${ }^{1}$ Onlara verilen bir diğer isim de kayla'dır. Etiyopya'da bir etnik köken olan Agaw dilinde bu isim, kırsal kesimde yaşayanlara ve onların ürettikleri ürünlere verilmektedir. ${ }^{2}$ Ayrıca onlara agaw denildiği de olmuştur. Bu tanımlamada onların İsrail kökünden geldikleri iddiası çürütülüp Hıristiyanlık öncesi pagan bir kabileye dayandırılma gayreti vardır. ${ }^{3}$ Onlara yönelik hakaret içeren birtakım terimler de kullanılmıştır. Buda şeklindeki bir isimlendirmede onların, 'kötü/şeytani bir göze' sahip oldukları ve insanlara zarar verebilecekleri ifade edilmeye çalışılır. ${ }^{4} \mathrm{Bu}$ bağlamda dile getirilen bu tanımlamaların hepsi,

1 Steven Kaplan, The Beta Israel (Falasha) in Ethiopia: From Earliest Times to the Twentieth Century, New York, 1995, s. 7-10.

2 Tudor Parfitt ve Emanuela Trevisan Semi (ed.), Jews of Ethiopia, London, 2005, s. 131. Kayla'nın anlamı hakkında farklı açıklama da bulunmaktadır. Buna göre Falaşa'lar kendi soylarını aşağıda anlatıldığı üzere Süleyman ile Makeda'nın (Belkıs) oğlu Menelik,'in takipçilerinden Yudah soyuna dayandırırlar. Çünkü onlar, Şabat günü nehirden geçmeyi yasak olduğu için reddetmişlerdir. Böylece kayla'nın anlamı, 'geçmeyi reddedenler' anlamına gelmektedir. Daniel Friedman ve Ulysses Santamaria, 'Identity and Change: The Example of Falashas, Between Assimilation in Ethiopia and Integration in Israel, Dialectical Anthropology, 15.1, 1990, s. 58.

3 Hagar Salamon, The Hyena People: Ethiopian Jews in Christian Ethiopia Contraversions, California, 1999, s. 21.

4 James Quirin, 'Caste and Class in Historical North-West Ethiopia: The Beta Israel (Falasha) and Kemant 1300-1900, The Journal of African History, 39.2, 1998, s. 208209; Gadi BenEzer, The Ethiopian Jewish Exodus, New York, 2002, s. 28. 
kendi içinde bazı sınırlandırmalar taşımaktadır. Bu makalede, daha yaygın kullanım olduğu için Falaşa terimini tercih etmekteyiz. Aynı zamanda bu terim, onların modern dönem dâhil, tarih içinde yaşadıkları birtakım 'göçlere' de işaret ettiği için buraya uygun düşmektedir.

\section{Kökenleri}

Etiyopya Yahudileri hakkında yazı yazanların karşısına çıkan en önemli meselelerden biri hiç şüphesiz, burada Yahudiliğin ne zaman ve nasıl başladığı ve bu Yahudilerin köklerinin nereye dayandığıdır. Etiyopya'da Yahudilerin varlığı ile ilgili farklı teoriler ortaya atılmıştır. Bunlar aşağıdaki gibi sıralanabilir:

i) Falaşa'ların, aslında Yakup'un on iki oğlundan biri olan $D a n^{\prime}$ ın soyuna mensup olduğu ileri sürülmektedir. Böylece bu kabile, kayıp kabile olarak ortaya konulmakta ve bunların Etiyopya'ya gittikleri zikredilmektedir. Bu konuda Seferad Yahudilerinin hahambaşılarından olan Ovadiah Yosef, 1973'de Falaşa'ların, Halaha' ya göre Yahudi kabul edilmeleri gerektiğini söyler. Çünkü ona göre Falaşa'lar, Dan'ın kayıp kabilesinin soyundandır. Bu bağlamda kendisinin Dan'ın soyundan geldiğini iddia eden IX. Yüzyıl Yahudilerinden Eldad Ha-Dani, Etiyopya Yahudilerinin kökenini de Dan'a bağlamaktadır. Eldad'dan sonra XVI. yüzyılda yaşamış Mısırlı Talmud ve Halaha bilgini David ben Abi Zimra da Etiyopya'dan Misır'a köle olarak getirilen Yahudilerin, Dan'ın soyundan olduğunu belirtmiştir. Ancak bununla beraber bu görüşü ispat edebilecek hemen hemen hiçbir tarihsel veri ortaya konulamamaktadır. ${ }^{5}$

ii) Etiyopya denildiğinde akla bir anlamda bu bölgenin medeniyet kaynağı olan Aksum Krallığı gelir. Yaklaşık olarak MÖ. 200 ile MS. 800 arasında varlığını sürdürmüş olan bu krallık, Etiyopya söz konusu olduğunda önemli bir yer işgal etmektedir. Özellikle II. Yüzyıldan sonra öne çıkmaya başlayan Aksum Krallığı'nda IV. Yüz-

\footnotetext{
Kaplan, The Beta Israel (Falasha) in Ethiopia, s. 24; Ulysses Santamaria, 'Ethiopian Jews in Israel', Dialectical Anthropology, 18.3-4, 1993, s. 406; Stephen Spector, Operation Solomon: The Daring Rescue of the Ethiopian Jews, New York, 2005, s. 3; Parfitt ve Trevisan Semi (ed.), Jews of Ethiopia, s. 34; Mitchell G. Bard, From Tragedy to Triumph: The Politics Behind the Rescue of Ethiopian Jewry, Connecticut, 2002, s. 2.
} 
yılda önemli bir değişiklik olur. Hıristiyanlık, Etiyopya'nın 'Konstantin'i olarak adlandırılan kral Ezana ve Zazana ${ }^{6}$ zamanında ülkenin resmi dini haline gelir. Ancak bu dönüşümden önce her ne kadar biraz abartılı da olsa Aksum Krallığı'ndaki insanların yarısının Yahudi olduğu dile getirilir.7 Aksum Krallığı'nda Yahudilerin bulunduğunu söyleyebilsek de onların buraya gelişleri ile ilgili çok net bir bilgi ortaya koymak zordur. İşte bu hususta Kebra Nagast ${ }^{8}$ isimli kitap bu boşluğu doldurmaya çalışmaktadır. Çünkü bu eser, Etiyopyalı Yahudi ve Hıristiyanların, kendi kökenleri ve Etiyopya'ya Yahudiliğin ulaşması ile ilgili bilgi vermektedir.

Kebra Nagast bir anlamda Etiyopya kimliğini ve tarihini Tora gibi Âdem'den başlatıp Süleyman'a getirir. Ardından Kudüs kralı Süleyman ile Etiyopya kraliçesi Makeda/Maqueda/Belkıs/Nicaule' $1 n^{9}$ Kudüs' te bir araya gelmelerinden bahseder. Kitapta aktarıldığına göre Süleyman, Tapınağı yaparken dünyanın dört bir yanındaki tüccarlara satabilecekleri ne tür ürünler var ise bunları getirmelerini söyler. Etiyopyalı bir tüccar da ürünlerini satmak için Süleyman'ın yanına gider ve onun bilgeliğinden etkilenir. Geri dönünce bunu kraliçe Makeda'ya anlatır. Bir süre sonra Süleyman'1 ziyarete eden Makeda da Süleyman'ın bilgeliğine hayran kalır.

6 Bu ikisinin gerçek ve tahta çıtıktan sonraki isimleri hakkında geniş bilgi için bkz.: E. Ullendorff, 'Note on the Introduction of Christianity into Ethiopia', Africa: Journal of the International African Institute, 19.1, (Ocak) 1949, s. 61.

7 Kaplan, The Beta Israel (Falasha) in Ethiopia, s. 17.

8 Kitabın, XIII veya XIV. Yüzyılda Yeshaq isimli bir Nebura'ed tarafından yazıldığı ileri sürülmektedir. (Christine Chaillot, The Ethiopian Orthodox Tewahedo Church Tradition, Paris, 2002, s. 76; De Lacy O'leary, The Ethiopian Church, London, 1936, s. 25; J. M. Harden, An Introduction to Ethiopic Christian Literature, London, 1926, s. 87; Kaplan, The Beta Israel (Falasha) in Ethiopia, s. 22; Komisyon, The Church of Ethiopia a Panorama of History and Spiritual Life, Addis Ababa, 1997, s. 75; Marilyn E. Heldman, 'Architectural Symbolism, Sacred Geography and the Ethiopian Church', Journal of Religion in Africa, 22, (Ağustos) 1992, s. 225). Bununla birlikte eserin, ilk olarak muhtemelen MS. 325'den önce var olduğu düşünülen Kıptice metinden, yaklaşık MS.1225' de Arapçaya, ardından da 1310'lu yıllarda Ge' ez diline tercüme edildiği de ileri sürülmektedir. Her ne kadar IV. Yüzyılda bu kitabın varlığı bilinse de bu dönemde eserin, Süleyman soyundan gelenlere işaret edecek şekilde ayrıca sistemleştirildiğinden de bahsedilir. (Jean Doresse, Ethiopia, (terc.: E. Coult), London, 1959, s. 114).

9 Etiyopya ile ilgili en erken seyahatnamelerden biri olan With the Mission to Menelik adlı kitabın yazarı E. Gleichen de Magueda veya Nikaula gibi isimleri zikretmektedir. Count Gleichen, With the Mission to Menelik, London, 1898, s. 148. 
Kraliçe burada yaklaşık 6 ay kaldıktan sonra ülkesine gitmek istediğini Süleyman'a bildirir.

Süleyman, Makeda'nın gitmek istediğini duyunca 'dünyanın öte yanından böyle güzel bir kadın gelmiş, acaba Tanrı bana ondan bir çocuk verecek mi?' diye kendi kendine sorar. Zira I. Krallar Kitabı'na göre Süleyman, 'kadın seven bir karaktere sahiptir'. ${ }^{10}$ Ardından Süleyman, kraliçeyi akşam yemeğine davet eder. Süleyman, ona kendisinin hazırlattığı baharatlı yiyecekler sunar. Herkes gittikten sonra, kraliçeye, sabah oluncaya kadar çadırında kalmasını söyler. Kraliçe, 'kendisine zorla sahip olmayacağına dair İsrail'in tanrısı adına yemin etmesini' ister. Süleyman yemin eder ve o da, kraliçenin, 'bu çadırdan hiçbir şey almayacağına' dair yemin etmesini talep eder. İkisi de birbirlerine yemin ederler ve her biri çadırın birer köşesinde hizmetçilerin hazırladığı yatağa yatarlar. Bu arada Süleyman, hizmetçilere, 'kraliçenin görebileceği bir yere sürahi ile su koymalarını' Makeda'nın anlamayacağı bir dilde söyler. Gecenin bir vaktinde kraliçe, aşırı derecede susamış bir şekilde uyanır ve tam bir bardak suyu içecekken, Süleyman onun elini tutar ve 'bana verdiğin yemini niye bozuyorsun' der. Kraliçe, 'bir su ile mi yemin bozulacak?' diye sorar. Süleyman da 'dünyada sudan daha değerli bir şey var mı?’ deyince kadın üzgün olduğunu ve yeminini bozduğunu kabul eder. Bunun üzerine Süleyman da artık yemininden azade olur ve o gece kraliçeyle birlikte yatarlar. ${ }^{11}$

Sabah olup kraliçe ayrılırken Süleyman, onun yanına gelir, parmağındaki yüzüğü çıkarır ve şunları söyler: "Bu yüzüğü al, eğer benden bir çocuğun olursa bu yüzük bir işaret olacaktır. Eğer bir erkek çocuk olursa o bu yüzügü taksın ve bana gelsin. Seninle yatarken rüyamda İsrail'in üzerine bir güneşin doğduğunu, fakat orada kalmayıp Etiyopya'ya gittiğini ve oranın üzerinde ışığını verdiğini gördüm. Muhtemelen senin aracılığınla ülken kutsanacak. Benim söylediklerimi yap ve bir tanriya itaat et". ${ }^{12}$

Süleyman'dan ayrılmasının üzerinden dokuz ay beş gün geçtikten sonra Makeda, bir erkek çocuk dünyaya getirir. Annesi onun adını 'Bayna-Lehkem' (Ebna/İbn Hakim) veya Menelik koyar. Çocuk on iki yaşına gelince, babasının kim olduğunu sorar. İlk olarak annesi kızar ve 'senin annen de baban da benim, başkasını arama'

$10 \quad$ I. Krallar, 11:1.

11 The Kebra Nagast, (terc.: E.A.W. Budge), Forgetten Books, 2010, s. 111- 134.

12 Age., s. 136. 
der. Ancak bir süre sonra babasının, Süleyman olduğunu ve ülkesinin çok uzakta bulunduğunu söyler. Çocuk yirmi iki yaşına gelince tüm savaş tekniklerini öğrenmiş yakışıklı bir genç olur ve annesine, 'babasını görmek için gideceğini ve geri döneceğini' ifade eder. Bayna-Lehkem gider ve babası Süleyman ile buluşur. ${ }^{13}$

İşte yukarıda anlatıldığı üzere Etiyopyalı Yahudiler ve Hıristiyanlar, bu bağlamda kendi köklerini Süleyman ve oğlu Bayna-Lehkem/Menelik I üzerinden Süleyman'a dayandırmaktadırlar. Etiyopya ile Süleyman arasında bir bağ olduğu yönündeki açıklamalar, sadece Kebra Nagast'a dayanmayıp bunun Kutsal Kitap'ta da izleri bulunmaktadır. Nitekim I. Krallar kitabında şunlar aktarılır:

Sebe Kraliçesi, Rab'bin adından ötürü Süleyman'ın artan ününü duyunca onu çetin sorularla sinamaya geldi. Çeşitli baharat, çok miktarda altın ve değerli taşlarla yüklü büyük bir kervan eşliğinde Kudüs'e gelen kraliçe, aklından geçen her şeyi Süleyman'la konuştu. Süleyman onun bütün sorularına karşılık verdi. Kralın ona yanıt bulmakta güçlük çektiği hiçbir konu olmadı. Süleyman'ın bilgeliğini, yaptırdığı sarayı, sofrasının zenginliğini, görevlilerin oturup kalkışını, hizmetkârlarının özel giysileriyle yaptığı hizmeti, sakilerini ve Rabbin Tapınağı'nda sunduğu yakmalık sunuları gören Sebe Kraliçesi hayranlık içinde kaldı.

Krala, 'ülkemdeyken yaptıklarınla ve bilgeliğinle ilgili duyduklarım doğruymuş' dedi. 'Ama gelip kendi gözlerimle görünceye dek inanmamıştım. Bunların yarısı bile bana anlatılmadı. Bilgeliğin de zenginliğin de duyduklarımdan kat kat fazla... Kral Süleyman, Sebe Kraliçesi'nin her isteğini, her dileğini yerine getirdi. Ayrıca ona gönülden kopan birçok armağan verdi. Bundan sonra kraliçe adamlarıyla birlikte oradan ayr1lıp kendi ülkesine döndü. ${ }^{14}$

I. Krallar'daki bu bilgilerin hemen hemen benzerini Yahudi tarihçi Josephus'un Jewish Antiquities ${ }^{15}$ adlı eserinde de görmekteyiz. Böylece hem I. Krallar hem de Josephus, Sebe Kraliçesi'nin ziyaretinden bahsettikten sonra Süleyman'ın kraliçeye, birçok hediye sunduğunu belirtirler. Ancak her iki metin de Süleyman'ın ona bir oğ $u l$ verdiğini

\footnotetext{
Age., s. 137-140.

I. Krallar, 10:1-13; II. Tarihler, 9:1-9.

15 Flavius Josephus, Jewish Antiquities, (terc. J. Thackerapy ve R. Malcus), VIII, (Loeb Classical Library), London, 1950, s. 164-167.
} 
zikretmez. Sadece metinde italik olarak gösterdiğimiz cümleye dayanarak, böyle bir durumun söz konusu olabileceği sonraki yorumcular tarafından belirtilir. Kebra Nagast'ta geçen anlatı, Kutsal Kitap metinlerindeki boşlukları doldurma amacına yönelik olarak okunabilir. ${ }^{16}$

Etiyopya Yahudilerinin kökenlerini Dan veya Süleyman'a dayandırmanın arkasında, onları Kutsal Kitap ile ilişkilendirmek gibi bir gayret okunabilir. Fakat bu iki hususun tarihsel olarak vaki olduğuna dair elde somut deliller bulunmamaktadır.

iii) Etiyopyalı Yahudilerin, MÖ. 586'daki I. Babil Sürgünü veya MS. 70'deki II. Sürgün sonrasında İsrail'den kaçıp Mısır'a, oradan da Etiyopya'ya yerleşen Yahudiler olduğu da dile getirilmektedir. ${ }^{17}$ Etiyopyalı Yahudilerin kökenlerini, Mısır'daki Yahudilere dayand1ranların başında Etiyopya uzmanlarından biri olan İtalyan Ignazio Guidi ile İsrail Devleti'nin ikinci başkanı Itzhak Ben Zvi (ö. 1963) gelmektedir.

Etiyopya Yahudilerinin, Misır ile olan ilişkisi şöyle dile getirilir: Mısır, I. sürgünden önce hali hazırda Yahudilerin yerleşim yerlerinden biriydi. II. Tapınak döneminde (MÖ. 586-MS. 70) bu cemaat gelişti ve 'Helenistik-Yahudiliğin' 18 önemli merkezlerinden biri haline geldi. Etiyopyalı Yahudi ve Hıristiyanların kullandığ 1 Ge'ez dilindeki tercümeye de kaynaklık eden Septuagint (LXX), İskenderiye' de yazılmıştı. Böylece bazı Mısırlı Yahudiler, Nil Vadisi üzerinden Etiyopya'ya geçmiş ve buradaki Yahudilere kaynaklık etmiş olabilir. ${ }^{19}$

16 Türk siyaset adamlarından ve Etiyopya ile ilgilenenlerden biri olan Kazım Karabekir de Falaşa'ların kökenini, Kebra Nagast'taki gibi Menelik I ile beraber Kudüs'ten gelenlere bağlamaktadır. Geniş bilgi için bkz.: Kazım Karabekir, İtalyaHabeş, İstanbul, 2001, s. 87.

17 Samuel Gobat, Journal of a Three Years' Residence in Abyssinia, (2. ed.), London, 1850, s. 467; Edward Ullendorff, 'Hebraic-Jewish Elements in Abyssinian Monophysite Christianity', The Journal of Semitic Studies, 1.3, 1956, s. 220.

18 Helenistik-Yahudilik ve Yahudilerin Mısır tarihi ile ilgili geniş bilgi için bkz. Dursun Ali Aykıt, Heristiyanlı̆̆ın Öncüsü Olarak İskenderiyeli Philo, İstanbul, 2010.

19 Bu teori ile ilgili geniş açıklama için bkz.: Kaplan, The Beta Israel (Falasha) in Ethiopia, s. 26-30. 
iv) Bir diğer teoriye göre bunların, yüzyıllar önce Hıristiyanlık veya paganizmden ayrılıp Yahudiliğe geçenlerin soylarına dayandıkları belirtilir. Bu bağlamda Agaw kabilesi, onların kökeni olarak gösterilmektedir. ${ }^{20}$

v) Güney Arabistan'dan göç eden Yahudiler21, Etiyopya'daki Yahudilerin kökenini oluşturmaktadır. Bu teoriyi ileri sürenler, ilk olarak Güney Arabistan ile Etiyopya arasındaki coğrafi yakınlığa ve bunlar arasındaki politik, ticari ve askeri ilişkilere dikkat çekmektedirler. Önemli Yahudi bilgelerinden biri olan Rabbi Akiba'nın (ö. 137), MS. 130'larda Arabistan'ı ziyaret ettiği ve burada Etiyopyalı bir yöneticinin bulunduğunu belirttiği aktarılmaktadır. Bu en azından Arabistan'da bir Yahudi cemaatinin varlığına ve onlardan birinin yöneticilik pozisyonuna sahip olduğuna dair en önemli işaretlerden biri olarak okunabilir. Bu hususta birçok araştırmacı, özellikle II. Sürgünden sonra çok sayıda Yahudi'nin, Arabistan'a geçtiğini belirtir. Böylece buradan da bir kısım Yahudi'nin, Etiyopya'ya geçmiş olabileceği dile getirilir. ${ }^{22}$

vi) Falaşa'ların, IV. Yüzyıldan sonra Hıristiyanlaşmaya başlayan Etiyopya'daki devlete ve burada yaşayan Etiyopya Kilisesi'ne bağlı kişilere yönelik bir başkaldırı hareketinin sonucunda oluştuğu da belirtilmektedir. ${ }^{23}$

Buraya kadar en azından Etiyopyalı Yahudilerin, kökenleri hakkındaki teorileri dile getirmeye çalıştık. Bu görüşlerden de anlaşllacağı üzere onların kökenini tam ve tarihi bir şekilde ispat edecek deliller nerdeyse yok mesabesindedir. Bu husus hala birçok soruyu ve sorunu kendi içinde barındıran bir mesele olarak devam etmektedir. Ayrıca bunun da ötesinde bir diğer önemli soru da şudur: Acaba Etiyopyalı Yahudiler, bölgeye Yahudiliği getirenlerin soylarından mı gelmekte; yoksa onların, Etiyopya'ya etkilerini devam ettiren yerli bir cemaat olarak mı anlaşılmaktadır?

20 Friedman ve Santamaria, 'Identity and Change, s. 58.

21 Hicaz ve Yemen bölgesi Yahudileri hakkında daha geniş bilgi için bkz.: Özcan Hıdır, Yahudi Kültürü ve Hadisler, İstanbul, 2006, s. 103-145.

22 Kaplan, The Beta Israel (Falasha) in Ethiopia, s. 30-32; Ullendorff, 'Hebraic-Jewish Elements in Abyssinian (Monophysite) Christianity', s. 220.

23 Ullendorff, 'Hebraic-Jewish Elements in Abyssinian (Monophysite) Christianity', s. 255; John T. Pawlikowski, 'The Judaic Spirit of the Ethiopian Orthodox Church: A Case Study in Religious Acculturation', Journal of Religion in Africa, 4.3, 19711972, s. 195; BenEzer, The Ethiopian Jewish Exodus, s. 27. 


\section{Tarihleri}

Etiyopyalı Yahudilerin kökenleri her nereye dayanırsa dayansın, hem Yahudiler hem de ülke için IV. Yüzyıl, önemli dönüşümün yaşandığı bir zaman dilimidir. Yukarıda da söylendiği üzere kral Ezana ve Zazana zamanında ülke, Hıristiyanlığı resmi din olarak kabul eder. Bu, ülkedeki Yahudileri derinden etkileyecek bir vakının başlangıcıdır. Hıristiyanlığının yayılmasına ve korunmasına öncülük eden bir diğer önemli imparator Caleb'tir (MS. 495-525). Onun yönetiminde Aksum Krallığı, Kızıl Denizi geçerek Güney Arabistan'ın büyük bir bölümünü yönetmiştir. Kilise de bu dönemde Güney Yemen ve Necran kentine kadar ulaşmıştır.

Caleb döneminde Etiyopyalı Yahudiler, önemli birtakım olaylarla karşı karşıya kalmışlardır. Aretas isimli nüfuzlu bir kişinin, Necran bölgesine vali olarak atanmasından sonra Etiyopya kaynaklarına göre Finnas, Arap ve Latin kaynaklara göre Zu Nuvas/Dhu Nuwas adındaki bir Yahudi kabile şefi (Himyeri Kralı), Necran'1 kuşatmış ve ardından da Aretas ve eşi başta olmak üzere buradaki H1ristiyanları öldürmüştür. Zu Nuvas, bölgedeki Hıristiyanlara iki seçenek vermiştir: Yahudiliği kabul etmek veya 'uhdud' ismi ${ }^{24}$ verilen içi ateş dolu çukurlara atılmak. Ayrıca Zu Nuvas, buradaki Hıristiyanlara ait evleri, kiliseleri ve tarlaları da ateşe vermiştir. $\mathrm{Bu}$ olayın zamanı hakkında 520 ile 540'lı yıllar gibi farklı tarihler verilmektedir. Bu haberi alan İskenderiye Patriği IV. Timothy, durumu İmparator Caleb'e bildirir ve bu kişiye karşı bir savaş açılmasını talep eder. Askerlerini bir an önce Kızıl Deniz'in diğer yakasına geçirmek isteyen Caleb, Roma İmparatoru Justinian'a bir mektup yazar ve ondan gemi ister. O da ona 60 gemi gönderir. Böylece Caleb, Necran'a girer, Zu Nuvas'ı öldürüp ordusunu dağıtır ve bölgede Hıristiyanlığ1 tekrar hâkim güç haline getirir. Böylece bir tarafta Etiyopyalı Yahudiler öte yanda da Hıristiyanlar karşı karşıya gelmiş ve Caleb'in de onayını alan bir proje olarak bölgenin Hıristiyanlaştırılması için birçok çalışma yürütülmüşsür. ${ }^{25}$

24 Kur'an'ı Kerim'de ismi geçen 'ashabı Uhdud'un (Buruç Suresi, 4-6) bu olaydan geldiği dile getirilir. Mustafa Fayda, İslamiyetin Güney Arabistan'a Yayılışı, Ankara, 1982, s. 18.

25 Lule Melaku, History of The Ethiopian Orthodox Tewahedo Church II-III, Addis Ababa, 2010, s. 1-2; Doresse, Ethiopia, s. 86-87; Chaillot, The Ethiopian Orthodox Tewahedo Church Tradition, s. 29; Fayda, İslamiyetin Güney Arabistan'a Yayılışı, s. 9-10; The Ethiopians An Introduction to Country and People, Oxford, 1973, s. 53. 
IX. yüzyıl, hem Etiyopyalı Hıristiyanlar hem de Falasha denilen Etiyopyalı Yahudiler için önemlidir. Çünkü bu dönemde Yodit/Judith/Gudit (852-892) isimli Yahudi bir kadın lider öne çıkar ve zaten giderek gerilemeye başlayan Aksum Krallığını ve bu bölgedeki H1ristiyanlığa ait unsurları paramparça eder. IV. Yüzyılda imparatorluğun dini, Hıristiyanlık olarak kabul ettirilmeye başlanınca buradaki Yahudiler, Aksum'un merkezinden uzaklaşıp dağlık ve iç bölgelere doğru çekilirler. İşte Ge'ez dilinde 'kendi aslî mekânından başka bir yere sürgün giden' anlamındaki Falasha kelimesi, bu Yahudi gruplara verilen addır. IX. Yüzyılda bu Falaşa Yahudilerinin sayısı giderek artar ve Aksum Krallığı'na vergi vermeyi reddederler. Bu dönemde onların başını yukarıda ismi geçen Yodit isimli kadın lider çeker. Hıristiyan Aksum Krallığı'na başkaldırıp Aksum'u yerle bir eder, Aziz Meryem Kilisesi'ni yıkar, rahipleri öldürtür, kitapları yakar ve buradaki dikilitaşları yıktırır.

$\mathrm{Bu}$ dönemde eğer kral ölür veya başına bir şey gelirse diye prensler, sıkı bir güvenlik ile korunup yüksek dağlarda bulunan yerlerde (Debra Damo Manastırının bulunduğu dağ gibi) saklanılırdı. Bunu duyan Yodit, Debra Damo Manastırına bir ordu gönderir. Fakat ordu başarısızlıkla dönünce kendisinin komuta ettiği bir orduyla buraya yönelir. Ancak hem gidilen mekânın çok dağlık ve sıkıntılı olmasından hem de havanın müsait olmamasından dolayı tekrar Aksum'a geri dönmeye karar verir. ${ }^{26}$

Yodit'in ölümünden sonra Hıristiyan lider Anbessa Wudem (892-912), orduyu tekrar toplayıp Falaşa Yahudilerine karşı harekete geçer ve Aksum'u yeniden ele geçirip Aziz Meryem Kilisesini inşa ettirir. Onun ölümünden sonra oğlu Dil Nead (912-922) Aksum krallığına hükmeder. Bu dönemde birçok Falaşa'nın Hıristiyanlığı kabul ettiği, ancak birçoğunun da Yahudi olarak kalıp Ge'ez diliyle ibadetlerini sürdürdükleri aktarılır. ${ }^{27}$

922-1270 tarihleri arasında Etiyopya'yı yöneten Zagwe hanedanlığı döneminde neredeyse Etiyopyalı Yahudilere ait bilgiye rastlanılmaz. Zagwe Hanedanlığının yıkılıp 1270'de Yikuno Amlak'ın (ö. 1285) tahta çımasıyla Süleyman soyundan geldiğini iddia edenler tekrar yönetime hâkim olurlar. Bu dönem, aynı zamanda birçok

26 Melaku, History of The Ethiopian Orthodox Tewahedo Church II-III, s. 30-33; Kaplan, The Beta Israel (Falasha) in Ethiopia, s. 65-66.

27 Melaku, History of The Ethiopian Orthodox Tewahedo Church II-III, s. 34. 
Falaşa'nın Hıristiyanlaştırılmasına yönelik faaliyetlerin yoğunlaştığı bir zaman dilimidir. Nitekim İmparator Amda Siyon (ö. 1344) Falaşa'lara yönelik misyon faaliyetine karşı ayaklanan Yahudilere bir ordu gönderip isyanı bastırmıştır. ${ }^{28}$ Yine Etiyopyalı önemli azizlerden biri sayılan Ewostatewos'un talebelerinden Gabra Iyesus, Dabra San manastırını, Falaşa Yahudilerinin de yaşadığı bölgede kurarak bir anlamda misyon faaliyeti yürütmüştür.

İmparator Dawit (1380-1410) zamanında Qozimos isimli bir keşiş, Hıristiyanlığı bırakıp Falaşa Yahudilerine katılır. Onun aziz bir insan olarak kabul edilmesi ve okuma yazma bilmesi nedeniyle kolayca Falaşa'ların içine girebildiği söylenmektedir. Nitekim Qozimos, Falaşa'lara Tanah'ın bir kopyasını yazar. Bu arada Falaşa lideriyle arası gayet iyi olan Qozimos, Hıristiyan keşişlere karşı bir ayaklanmanın başını çeker. Falaşa'larla yapılan bu ayaklanmada birçok kilise yakılır ve kırk civarında din adamı da öldürülür. Olaydan haberdar olan imparator, onların üzerine bir ordu göndererek ayaklanmayı bastırır. ${ }^{29}$

Her ne kadar Amda Siyon ve Dawit zamanında küçük çaplı mücadeleler olmuşsa da Falaşa'lara yönelik sistemli bir baskı 14141429 arasında imparatorluk yapan Yeshaq I zamanında gerçekleşir. 'Falaşa'lara yönelik politikanın değişmesinde ne etkili olmuştur?' gibi bir soruya farklı cevaplar verilebilmektedir. Bunlardan birine göre ondan önce de birçok yönetici, Falaşa'ların yaşadığı Wagara ve Dambya gibi bölgelerin verimli topraklarına gıpta etmiştir. Yeshaq, onların elindeki bu toprakları almak için Falaşa'lara yönelik yaklaşımı değiştirmiş olabilir. Bu nedenle olsa gerek Yeshaq, Yahudilerin Hıristiyan olmasını aksi takdirde ellerindeki toprakların alınacağını ve Falaşa (topraksız, sürgün edilmiş) olacakları yönünde bir ferman

28 Steven Kaplan, The Monastic Holy Man and the Christianization of Early Solomonic Ethiopia, Almanya, 1984, s. 101.

29 Kaplan, The Monastic Holy Man and the Christianization of Early Solomonic Ethiopia, s. 101; Richard Pankhurst, 'The Falashas or Judaic Ethiopians in Their Christian Ethiopian Setting', African Affairs, 91.365, (Ekim) 1992, s. 568; Kaplan, The Beta Israel (Falasha) in Ethiopia, s. 55-56; James Quirin, 'The Process of Caste Formation in Ethiopia: A Study of the Beta Israel (Felasha) 1270-1868, The International Journal of African Historical Studies, 12.2, 1979, s. 239. 
yayımlar. ${ }^{30}$ Yeshaq'dan sonra Etiyopya' da Hıristiyan kültürün zirve yaptığ1 ve Hıristiyanlığın ülkede benimsetilmesi hususunda diktatörce tutumlara sahip Zara Yakob (ö. 1468), önceden Hiristiyanlığ benimseyip ardından Yahudiliğe geçenlerin çıkarttı̆̆ı ayaklanmaları bastırmakla uğraşmıştır. ${ }^{31}$

Etiyopya' da ayrı bir kimlik olan Galla'lılar içerisinden, Ahmed b. İbrahim el-Gazi yönetimindeki Müslümanlar, Etiyopya'yı hâkimiyet altına almak için 1520'lerde Adal (Harar) bölgesinden sald1rıya geçerler. Önce ülkenin kuzey bölgelerine ardından da tümüne el-Gazi'nin liderliğinde hâkim olan Müslümanlara, Hıristiyan yönetimi altında sıkıntı çeken Yahudiler, ilk aşamada sıcak bakarlar. Böylece hem bağımsızlıklarını kazanacaklarını hem de ellerinden alınan topraklara tekrar sahip olacaklarını düşünürler. Ancak bir süre sonra bu isteklerinin yerine gelmediğini görmelerinden dolayı Müslümanlara karşı Hıristiyanlara yardım etmek için Christopher de Gama'nın ${ }^{32}$ liderliğinde gelen (1542) güçlere destek verirler. ${ }^{33}$

İmparator Susenyos (1607-1632), Etiyopya Kilisesi'ni birakıp Katolik inancı benimsemesiyle dikkatleri ve aynı zamanda tepkileri üzerine çekmiş bir yöneticidir. İlk başlarda imparatora yakın bir duruş sergileyen Falaşa'lar, bir süre sonra Katolik imparatora karşı çıkan Etiyopya Kilisesi taraftarlarına destek verince Susenyos'un, 'Falaşa'lar nerede bulunursa öldürülüp yok edilecektir' fermanına maruz kalmışlardır. Bu zorlu süreci atlatan Falaşa'lar, bıçak ve buna

30 Kaplan, The Monastic Holy Man and the Christianization of Early Solomonic Ethiopia, s. 101; Yohannes, Filsata: The Feast of the Assumption of the Virgin Mary, s. 36; Kaplan, The Beta Israel (Falasha) in Ethiopia, s. 58, 66; Quirin, 'Caste and Class in Historical North-West Ethiopia, s. 201; James Quirin, 'Oral Tradations as Historical Sources in Ethiopia: The Case of the Beta Israel (Falasha)', History in Africa, 20, 1993,s. 299.

31 Kaplan, The Beta Israel (Falasha) in Ethiopia, s. 59. Özellikle bu dönemde öne çıkan ve kendilerine ayhud denilen bir oluşumdan bahsedilmektedir. Etiyopyalı Hıristiyanlar tarafından en genelde Hıristiyan olmayanlar için kullanılan bu terim, aynı zamanda Yahudiler için de kullanılmıştır. Ayrıca dini-siyasi ayaklanmalar da ayhud şeklinde isimlendirilen bir oluşum tarafından yapılmaktadır denilerek, Hıristiyan iken Yahudi olmuş kişilere de bu isim verilmiştir.

32 Avrupa' dan hareket edip Hindistan'a doğrudan giden ve Ümit Burnu'nu keşfeden Vasco De Gama'nın yeğenidir.

33 Kaplan, The Beta Israel (Falasha) in Ethiopia, s. 83-84; Quirin, 'The Process of Caste Formation in Ethiopia', s. 242. 
benzer alet yapımı gibi işlerin yanında bir de inşaat alanında uzmanlık kazanınca toplumda tekrar bir yer edinmeye başlarlar. ${ }^{34}$

Gondar şehrinin başkent yapılması nedeniyle Gondar Dönemi (1632-1755) diye adlandırılan zaman diliminde, Falaşa'lar, Gondar'daki sarayların inşa edilmesinde önemli rol oynarlar. Aynı zamanda onlar arasında askeriyeye seçilenler ve hatta Gondar'da kendilerine arazi verilenler de olur. Böylece toplumun içinde değişik yerlerde ikamet ederler. Bu süreçte en azından Etiyopya'daki topluma biraz daha entegre olmuş bir durumları vardır. ${ }^{35}$

Etiyopya' da tam anlamiyla etkin bir imparator olmaması nedeniyle 1769 ile 1855 yılları arasına 'Prensler/Hâkimler Dönemi' (Zamana Mesafent) denilir. Tewodros/Theodore II (ö. 1868), ülkeyi tekrar kendi yönetimi altında toplayarak bu döneme son verir. ${ }^{36} \mathrm{Fa}-$ laşa'lar, bir önceki dönemde nispeten elde ettikleri kazanımları, kaybederler ve Etiyopya'da yalnız ve izole bir hayat sürmek zorunda kalırlar. Ülke karışıklık içinde olduğundan yeni bina yapmak veya eskileri restore etmek gibi işler düşünülemediğinden Falaşa'lar, inşaat alanında kazandıkları yeteneklerini sergileyemez ve bu nedenle tekrar bıçak, kazma gibi alet yapımına ve elden geldiğince tarımla uğraşmaya başlarlar. ${ }^{37} \mathrm{Bu}$ da onların toplumsal statülerindeki kaybı gösteren önemli işaretlerden biridir. 1855'de J. Martin Flad ve J. L. Krapf isimli iki Protestan misyoner, Tewodros'tan misyon çalışması yürütmek için izin ister. $\mathrm{O}$ da bunu iki şartla kabul edeceğini söyler: i) Hıristiyan olmayan unsurlar (animist ve Falaşa'lar) arasında misyon faaliyetlerini sürdürmek ve ii) Hıristiyanlığı kabul eden herkesin, Etiyopya Kilisesi'ne bağlı olduğunu kabul etmek. ${ }^{38}$ Böylesi bir anlaşma Falaşa Yahudilerini potansiyel misyon alanı olarak ortaya çıkartmıştır.

\footnotetext{
Quirin, 'The Process of Caste Formation in Ethiopia', s. 243.

Quirin, 'The Process of Caste Formation in Ethiopia', s. 244-247.

36 Donald Crummey, 'Church and Nation The Ethiopian Orthodox Tawahedo Church', The Cambridge History of Christianity, (ed. Michael Angold), V, Cambridge, 2006, s. 465.

37 Quirin, 'The Process of Caste Formation in Ethiopia', s. 247-248.

38 D.H. Shinn ve T.P. Ofcansky, Historical Dictionary of Ethiopia, Maryland, 2004, s. 91; John Baur, 2000 Years of Christianity in Africa, Kenya, 1998, s. 159; Melaku, History of The Ethiopian Orthodox Tewahedo Church II-III, s. 148-149; Kaplan, The Beta Israel (Falasha) in Ethiopia, s. 118; Steven Kaplan, 'The Beta Israel (Falasha) Encounter with Protestant Missionaries: 1860-1905', Jewish Social Studies, 49.1, (Kış) 1987, s. 28.
} 
Etiyopya tarihinde önemli dönüm noktalarından birini oluşturan büyük kıtlk, 1888-1892 yılları arasında sürmüş ve ülkeyi hem ekonomik hem de sosyal açıdan felç etmiştir. Etiyopya'da yaşayan tüm insanlarda olduğu gibi bu kıtlık sürecinde, birçok Falaşa da yer değiştirmek zorunda kalmıştır. Ülkenin bütününde ciddi oranda nüfus azalması yaşanırken hali hazırda belirli bölgelerde yoğunlaşan ve kıtlık nedeniyle buradan ayrılmak zorunda kalan Falaşa'ları, iki önemli tehlike beklemektedir: i) Bölgelerinden göç etmeleri nedeniyle asimile olma ve ii) kitlı nedeniyle nüfuslarını daha da azalması. Sıkı sıkıya bağlı oldukları Falaşa olmayanlarla bir şey yiyipiçmeme kuralı, kıtlığın olduğu bir ortamda yürümez hale gelir. Hayatta kalmak için nerede ve kimde yemek bulunursa onlarla birlikte olmak gerekir. Bu da birçok Falaşanın, Hıristiyan olmasının sebeplerinden biridir. ${ }^{39}$

Etiyopya'daki Falaşa'ların Yahudi olduğunun batılılar tarafından kabul edilmesi oldukça zor bir süreç olmuştur. Bu hususta önderlik eden ilk Avrupalı (Alman) Rabbi, Eisenstadt'lı Azriel Hildesheimer'dir (ö. 1899). O, buradakilerin Yahudi olduklarını ve yardım edilmesi gerektiğini ilk kez deklare eder. ${ }^{40}$ Ardından XIX. yüzyılda Etiyopya'daki Falaşa'ların misyon faaliyetleri sonucunda Hıristiyanlaştırılmaya çalışıldığına dair haberler gelmeye başlar. Bunun üzerine Alliance İsraelite Universelle adlı kuruluşun görevlendirmesiyle Fransiz Yahudisi olan Joseph Halevy, 1867'de Etiyopya'ya gider. Döndükten sonra raporunda Falaşa'ların korunması ve onlar için okul açılması çağrısında bulunur. Böylece bu zaman dilimine kadar dünyanın diğer tarafındaki Yahudi gruplardan izole bir şekilde yaşayan Falaşalar, Yahudi dünyasıyla tekrar iletişime geçerler. Falaşa'lar her ne kadar buna sevinseler de bu hususta sonuç almak için bir kırk yıl daha beklemek zorunda kalırlar. ${ }^{41}$

Joseph Halevy'nin talebelerinden ve 'Falaşa'ların babası' olarak isimlendirilecek olan Jacques Faitlovitch'in 1904' de Etiyopya'ya gelmesi, Falaşa'lar için bir dönüm noktası olmuştur. O, Etiyopya'nın Gondar bölgesinde yaşayan Taamrat Emmanuel ve Getiah Yere-

39 Kaplan, The Beta Israel (Falasha) in Ethiopia, s. 143-149.

40 Friedman ve Santamaria, 'Identity and Change, s. 62; Bard, From Tragedy to Triumph, s. 6.

41 Spector, Operation Solomon, s. 8; BenEzer, The Ethiopian Jewish Exodus, s. 30; Bard, From Tragedy to Triumph, s. 7. 
miah isimli iki erkek çocuğunu eğitim almaları için Avrupa'ya getirir. Böylece onların geriye döndüklerinde kendi bölgelerindeki Falaşa'lara dinlerini öğretmede katkıda bulunmasını sağlamaya çalışmıştır. Ardından o, Etiyopya'da Falaşa'ların eğitimini gerçekleştirmek için 1924'de Addis Ababa'da bir okul açmıştır. 1935'de İtalyanların, Etiyopya'yı işgali sırasında bu okul yıkılır. Ardından Faitlovitch, İsrail devletinin kurulmasından sonra Falaşa'ların, İsrail'e değişik operasyonlarla taşınmasının da öncülüğünü yapmıştır. ${ }^{42} \mathrm{Bu}$ süre içerisinde Falaşa'lar'ın gerçekten Yahudi olup olmadıkları ile ilgili birçok tartışma yapılmış ve bu hususta Yahudi din bilginleri ikiye ayrılmıştır. Bu bağlamda onların Yahudi olup olmadıkları ile ilgili farklı görüşler, dünya Yahudilerinin bu hususta rol almalarındaki gecikmenin nedenlerinden biridir. Tüm bu tartışmaların içinde 1970'lerin ortalarında Sefarad ve Aşkenaz Başhahamlar, Etiyopya'daki Falaşa'ların Yahudi olduklarını ${ }^{43}$ ve 'İsrailin Dönüş Yasası' kapsamında İsrail'e getirilmelerini deklare eder. Böylece 1975'de İsrail Devleti'nin de onların Yahudi olduklarını kabul etmesiyle, göç sürecinin önü açılmış olur. 1984-85' de yapılan 'Musa Operasyonu' ile Etiyopya'dan Sudan'a kaçırılan 7.700 Falaşa İsrail'e getirilir. 1985'in Mart ayında 'Kraliçe Sebe Operasyonu' ile 1.200 civarında kişi daha göç ettirilir. 1991'deki 'Süleyman Operasyonu' 44 ile de 14.400 Etiyopyalı Yahudi Addis Ababa'dan 36 saat içinde İsrail'e ulaştırılır. Yine 1990'larda Fresmura, Fallas Mura veya Flesmura denilen önceden Yahudi iken XIX. Yüzyılda Hiristiyan olan binlerce kişi de Etiyopya'ya getirilir. Ayrıca özellikle Sebe ve Süleyman Operasyonlarında, $\mathrm{ABD}$ ve onun istihbarat örgütü CIA, maddi ve manevi ciddi katkılarda bulunmuştur. ${ }^{45}$ Tüm bu süreçlerin arka-

42 Friedman ve Santamaria, 'Identity and Change, s. 63-64; Parfitt ve Trevisan Semi (ed.), Jews of Ethiopia, s. Xiii, 75; BenEzer, The Ethiopian Jewish Exodus, s. 25, 30-31.

43 Onların Yahudiliğini ispatlamak adına DNA testleri dahi yapılmıştır. Buna bir örnek için bkz.: Gerard Lucetto ve Pierrre Smets, 'Origins of Falasha Jews Studied by Haplotypes of the Y Chromosome', Human Biology, 71.6, (Aralı) 1999.

44 Süleyman Operasyonu hakkında geniş bilgi için bkz.: Stephen Spector, Operation Solomon: The Daring Rescue of the Ethiopian Jews, New York, 2005.

45 BenEzer, The Ethiopian Jewish Exodus, s. 32-33; Weil, 'Ethiopian Jewish Women', s. 79. Falaşa'lar'ın İsrail'e getirilmesi ve bunun arkasındaki siyasi tutumlar hakkında geniş bilgi için bkz.: Mitchell G. Bard, From Tragedy to Triumph: The Politics Behind the Rescue of Ethiopian Jewry, Connecticut, 2002. 
sında İsrail devletinin kurulması ve Siyonist eğilimin tüm Yahudileri İsrail'de toplamak gibi bir tutumunun olduğunu da belirtmek gerekir.

2002 yılında İsrail'de bulunan Falaşa'ların sayısı, 85.000 civarındadır. Bunların 23.000'i, İsrail'de doğmuştur. Falaşa'ların İsrail'de yoğun olarak bulunduğu bölgeler şunlardır: Netanya, Rehovot, Hayfa, Hadera, Ashdod, Ashkelon ve Beersheva. ${ }^{46}$ Böyle çok sayıda Falaşa'nın İsrail'e gelmesi, hem akademik camiada hem de hükümet bazında ciddi araştırma konuları oluşturmuştur. Akademik anlamda Falaşa'ların, İsrail'e uyumu, evlilik, çocukların konumu, İsrail'deki Yahudilikten farklı inanç ve uygulamaları birçok çalışmayı peşinden getirmiş ve hâlâ çalışılması gereken bir süreçtir. Hükümet açısından da bunların sosyal ve hukuki konumları ile onların İsrail'e uyumu ciddi bir alan teşkil etmiştir. Nitekim bu hususta bir ilerleme kat etmek adına Özümsetme/ İltihak Merkezleri (Absorption Centers) kurulmuştur. Göç eden Falaşa'lar, bu merkezlerde topluma uyum sağlamaları için eğitilmektedir.

\section{İnançları}

Değişik operasyonlarla İsrail'e getirilen Falaşa'lar, dünyadaki en önemli yerin Yerussalem (Kudüs) olduğuna inandıkları için buraya gelmeyi arzulamaktaydılar. Nitekim birçok göçmenle yapılan mülakatta, sinagogdaki dini törenlerdeki en önemli taleplerden birinin de Kudüs'e gitmek olduğu ifade edilmektedir. Bunu bir anlamda vadedilmiş kutsal topraklara dönmek olarak anlayan Falaşa'lar, yoldaki her türlü zorlukta Tanrı'nın onlara yardım edeceklerine inanmaktadırlar. ${ }^{47}$ Muhtemelen onlar, kendilerinin Etiyopya'dan çıkışları ile Musa'nın Mısır'dan çıkışı arasında bir bağ kurarak, bu uzun ve sıkıntılı süreci aşmayı başarmış olmalılar.

Falaşa'lar için Orit (Pentatök) birincil öneme sahip kutsal kitap olup onun dişında diğer Tanak metinleri, ikincil derecede de olsa kutsal kitap literatürüne dâhildir. Günümüz Yahudi kanonik listesinde bulunmayan bazı kitaplar da (İbrahim'in Ahdi, İshak'ın Ahdi,

\footnotetext{
46 Parfitt ve Trevisan Semi (ed.), Jews of Ethiopia, s. Xiv.

47 BenEzer, The Ethiopian Jewish Exodus, s. 61-62, 73.
} 
Musa'nın Konuşması, Musa'nın Ölümü48 gibi) onların kanonik listesinde yer almaktadır. Bununla birlikte tarihsel süreçte diğer Yahudi gruplardan izole olmaları nedeniyle olsa gerek Mişna ve Talmud gibi sözlü gelenekler, Falaşa'lar tarafından bilinmez ve burada geçen hükümler uygulanmaz. İbranice bilmedikleri için ibadet dili Ge'ez'dir. ${ }^{49}$

İbadetlerde sadece haham (qes), başını örterken, diğerleri örtmez. Ortodoks Yahudilik'te olduğu gibi kadın ve erkekler, genellikle bir kulübe şeklinde olan sinagog'da ayrı otururlar. Ayrıca ibadet esnasında Kudüs'e yönelirler. ${ }^{50}$

Falaşa'lar, kendi dininden olmayan biriyle fiziki temastan uzak durmuşlardır. Çünkü onlara göre dini açıdan kirli olan diğer inançlardan biriyle fiziksel temasta bulunmak, kendilerinin de kirlenmesine neden olmaktadır. Bu nedenle kazara veya mecburen böyle bir temasta bulunulmuşsa eve girmeden önce beden ve elbiseler hemen temizlenmelidir. Falaşa'ların genellikle su kenarlarına yakın yerlerde oturmalarında bu husus önemli bir rol oynamış olabilir. Ancak bununla beraber özellikle gençler arasında bu uygulama giderek zayıflamış ve Hıristiyanlarla yemek yiyenler dahi bulunmuştur. Bu hususta yaşlılar gençlere nazaran çok daha sıkı bir şekilde buna uymaya çalışmaktadırlar. ${ }^{51}$

Genellikle tarım ve hayvancılıkla hayatlarını sürdüren Etiyopyalılar, tarlada çalışırken, hayvanlarını otlatırken veya başka durumlarda farklı inançlara sahip insanlarla birlikte iş yapmak zorunda kalabilirler. Bu durumda birbirine dokunmamak gibi bir uygulama işleri daha da zorlaştırmaktadır. Bu hususta her ne kadar kişinin din algısına bağlı olarak farklı tutumlar olsa da şu tür yorumlar yapılmıştır: Hıristiyanlarla injera ${ }^{52}$, meyve, sebze ve kahve

48 Bu kitap hakkında bkz.: Max Wurmbrand, 'Remarks on the Text of the Falasha Death of Moses', Bulletin of the School of Oriental and African Studies, 25. 1-3, 1962.

49 Edward Ullendorff, 'Hebraic-Jewish Elements in Abyssinian (Monophysite) Christianity', Journal of Semitic Studies, 1.3, 1956, s. 254; Shalva Weil, 'Ethiopian Jewish Women: Trends and Transformation in the Context of Transnational Change', Nashim: A Journal of Jewish Women's Studies and Gender Issues, 8, 2004, s. 74.

50 Bard, From Tragedy to Triumph, s. 4.

51 Salamon, The Hyena People, s. 20; Quirin, 'The Process of Caste Formation in Ethiopia', s. 257.

52 Etiyopyaya has bir tür pide. 
içebilirsin; ancak onlarla et yiyip onların kaplarında pişen bir şeyi yiyemezsin. ${ }^{53}$

Şabat, Falaşa'ların da diğer Yahudiler gibi iş yapmadıkları bir gündür. Bu nedenle bunun gündelik yaşamda farklı tezahürleri ortaya çıkar. 'Şabat sütü' denilen bir uygulama da Hıristiyan ve Falaşa arasındaki iletişime ilginç bir örnektir. Bilindiği üzere Falaşa'lar, diğer Yahudilerde olduğu üzere Cumartesi (Şabat) günü bir iş yapamazlar. Bunun içerisine süt sağmak da dâhildir. Dolayısıyla Hıristiyan bir komşusu olan Falaşa, Şabat günü süt sağamayacağ1 için kendi hayvanının sütünü bahsi geçen komşusunun sağmasına müsaade eder ve buna da Şabat sütü adı verilir. ${ }^{54}$ Etiyopya'dan İsrail'e göç esnasında bir taraftan doğanın zorluklarının üstesinden gelmeye çalışılırken; öte yandan da dini kurallara uyma düşüncesi oldukça sıkıntılı durumları da peşinden getirmiştir. Bu hususta bir anısını anlatan Falaşa, şöyle demektedir:

Gece vaktiydi. Bir anda ateş açılmaya başlandı. Gece olduğu için kimse etrafta ne olup bittiğini göremiyordu. Saldırganlar, kess'in (haham) beyaz atını görmüş ve o yöne doğru ateş ediyordu. At vuruldu ve yere düştü. Tabii ki kess' in eşyaları, o ata bağlanmıştı. Eğer bu eşyaların bağlı olduğu ip, attan çözülmezse tüm eşyaları murdar hale gelecekti. Kimse ateş altında ayağa kalkamazken, kess kalktı ve bu ipi attan çözdü. Sabah olunca at ve diğer eşeklerin öldüğünü gördük. Rehberimiz, hemen hareket etmemiz gerektiğini söyledi. Fakat o gün Şabat olduğu için biz hareket etmeyi reddettik. Rehber, hayati tehlikemiz olduğunu söylediği halde biz durmayı yeğledik... 55

Falaşa'ların hayatında önemli olan hususlardan biri de cenaze merasimidir. Ölen kişinin cenaze merasimi, eğer büyük bir engel yoksa aynı günde yapılır. Tora'ya sıkı sıkıya bağlı olan bu Yahudiler, Sayılar Kitabı'nda ${ }^{56}$ geçtiği üzere cesede dokunan bir kişinin yedi gün diğer insanlardan tamamen ayrılması ve ardından yedinci günün arifesinde de suç takdimesi olarak sunulmuş ve yakılmış kızıl bir buzağı külünün üstüne atılmasıyla temizleneceğine inanmaktadırlar. Bu nedenle bir Falaşa'nın cesedinin taşınmasında Hıristiyan

\footnotetext{
53 Salamon, The Hyena People, s. 26.

54 Salamon, The Hyena People, s. 28-29.

55 BenEzer, The Ethiopian Jewish Exodus, s. 77.

56 Sayılar, 19.
} 
komşular merkezi bir rol alırlar. Böylece cesedin taşınmasından mezarın kazılmasına ve hatta cesedin mezarın içine konulmasına kadar yardımda bulunurlar. Her ne kadar bir Falaşa da Hıristiyan komşusunun veya dostunun cenaze törenine katılsa da tamamen pasif bir rol oynar. Çünkü o, cesede dokunamaz, Hıristiyan mezarlığına giremez ve onun gömülmesine de yardım edemez. Bu bağlamda bir Falaşa ancak ağlamak gibi bir fonksiyon icra edebilir. ${ }^{57}$ Ölen kişi eğer erkek ise sağ tarafına; bayan ise sol tarafına yatırılarak gömülür. ${ }^{58}$ Ölen kişinin yakınları, yedi gün yas tuttuktan sonra tazkar ismi verilen ve dördünde, yedisinde ve bir yıl geçtikten sonra özel anma günleri düzenlerler. Bir kişinin öldüğünün akrabalara ve yakınlara duyurulması çok önemlidir. Bu nedenle ilk önce en yakın akrabalara ve diğer yakınlara duyurularak ölüm ilan edilmeye çalışılır. Çünkü eğer bir akraba, ölüm haberini yabancı birinden alırsa, bunu kendine yönelik bir hakaret olarak algılamaktadır. ${ }^{59}$

Pentatök'de ismi geçen bayramların dışında bir bayram kutlamazlar. Bu nedenle Hanuka ve Purim, Falaşa'lar tarafından bayram olarak kabul görmemektedir. ${ }^{60}$ Etiyopyalı Yahudilerin diğer Yahudilerden farklı olarak kutladıkları önemli bayramlardan biri sigd'tir (Mehlella da denilmektedir). Sigd, secde etmek anlamina gelir ve Yom Kipur'dan 50 gün sonra kutlanılır. Bu bayram, Musa'nın Sina'da Tora'yı alması ve Ezra'nın İkinci Tapınak döneminde tekrar kutsal metinleri çıkartması anısına kutlanılır. Musa'nın Tora'yı almak için Sina Dağı'na çıkmasında olduğu gibi onlar da bu günde yüksek bir dağa çıkarlar ve orada dua okurlar. Bu süre zarfında oruçlu olup bir şey yiyip içmezler, dua esnasında secdeye kapanırlar ve Kudüs'e geri dönmek için dua ederler. Ardından köye tekrar gelirler ve bir festival havasında kurbanlar kesilir ve ziyafet çekilir. Tarih bölümünde de anlatıldığı üzere Falaşa'ların birçoğu aliyalarla İsrail'e getirilmiştir. İsrail' deki Falaşa'lar, bu günü hâlâ kutlamaktadırlar ve bu günde Ağlama Duvarına gelip burada dualarını yerine

57 Salamon, The Hyena People, s. 48-50; Quirin, 'The Process of Caste Formation in Ethiopia', s. 256.

58 Charles Singer ve Woldah Haimanot, 'The Falashas', The Jewish Quarterly Review, 17.1, (Ekim) 1904, s. 143.

59 BenEzer, The Ethiopian Jewish Exodus, s. 24; Parfitt ve Trevisan Semi (ed.), Jews of Ethiopia, s. 151.

60 Santamaria, 'Ethiopian Jews in Israel', s. 407; Parfitt ve Trevisan Semi (ed.), Jews of Ethiopia, s. 188. 
getirmektedirler. İsrail Parlamentosu (Knesset), 2008'de bu günü milli bayram olarak tanımıştır. ${ }^{61}$

Bilindiği üzere genel anlamda kurban söz konusu olduğunda Yahudiler, bu ritüeli Tapınağa has kıldıkları için günümüzde Yahudiler arasında kanlı kurban fenomeni uygulanmamaktadır. Ancak bir önceki paragrafta da belirtildiği üzere Falaşa'lar, Yahudi takvimine göre Nisan ayının 15'ine denk gelen Fisıh bayramında kurban kesmeye devam etmişlerdir. Kurbana yönelik bu tutumları nedeniyle onlar, diğer Yahudi gruplardan ayrılmaktadırlar. ${ }^{62}$

Yom Kipur ile ilgili uygulamaları, genel Yahudi çizgisinden biraz farklıdır. Onlar bugünde yukarı-aşağı zıplar, sesler çıkararak ıslık çalarlar ve dans ederler. Bu tür uygulamaların, günahlarını silip atacaklarına inanırlar. Onların ayırıcı özelliklerinden biri de keşiş (manakosat) ve keşişelere sahip olmalarıdır. Bunlar, günde yedi vakit ibadet etmeleriyle, Etiyopya Kilisesi'ne bağlı rahiplere benzemektedirler. Yahudilik dini hiyerarşisi içerisinde Falaşa'lar'a göre keşişler, birinci sırada gelmektedir. Litürjinin oluşmasında büyük role sahip olduğu düşünülen ve en önemli keşişlerden biri, XV. Yüzyılda yaşamış ve önceden Hıristiyan iken Yahudiliğe geçmiş Abba Sabra'dır. ${ }^{63}$ 1970'lere kadar devam ede gelen manastır hayatı (son temsilciler olarak Abba Wedaja ve Abba Simon'un isimleri geçmektedir) giderek yok olmuş ve keşişlerin rollerini, artık rahipler (Qessoch) icra etmeye başlamıştır. Manastır ve keşişlik gibi bir sistemlerinin olması da Falaşa'lar'ı günümüz Yahudilerden ayırmaktadır. ${ }^{64}$ Ayrıca Falaşa'lar arasında günah çıkarma gibi bir uygulamanın olması da ilgi çekicidir. Bu tür bir pratik için bir haham

61 Salamon, The Hyena People, s. 57; http://www.knesset.gov.il/lexicon/eng/sigd_eng.htm (02.10.2013); Spector, Operation Solomon, s. 7.

62 Kaplan, The Beta Israel (Falasha) in Ethiopia, s. 153; Mordecai Roshwald, 'Marginal Jewish Sects in Israel (II)', International Journal of Middle East Studies, 4.3, (Temmuz) 1973, s. 345; Bard, From Tragedy to Triumph, s. 4.

63 Abba Sabra ve Abba Saga Amlak gibi kişilerin, Falaşa'lar arasında manastır teşkilatını oluşturdukları da ileri sürülmektedir. Parfitt ve Trevisan Semi (ed.), Jewws of Ethiopia, s. 184; Quirin, 'Oral Tradations as Historical Sources in Ethiopia', s. 301-302; Pankhurst, 'The Falashas or Judaic Ethiopians in Their Christian Ethiopian Setting', s. 569.

64 Spector, Operation Solomon, s. 7; Kay Kaufman Shelemay, 'Historical Ethnomusicology: Reconstructing Falasha Liturgical History', Ethnomusicology, 24.2, 1980, s. 239; Parfitt ve Trevisan Semi (ed.), Jews of Ethiopia, s. 156-157; Quirin, 'Oral Tradations as Historical Sources in Ethiopia', s. 305. 
çağrılır, ona günahlar itiraf edilir, o bu günahları bağışladığını söyler ve ardından ona para veya değerli bir ürün (hayvan, meyve vb.) verilir. ${ }^{65}$

Etiyopya'daki Yahudilerle Hiristiyanlar arasında bazı teolojik hususlarda farklılıklar ve anlaşmazlıklar vardır. Bunların başında 'Orit (Tora) mi yoksa Wangel (Yeni Ahit) mi daha kutsaldır? İsa, tanrı mıdır? İsa'yı kim haça gerdi?' gibi sorular gelmektedir. Orit'in doğrudan tanrıdan alınmış bir vahiy olduğuna inanan Falaşa'lar, Wangel'in insan eliyle yazıldığını ve bozulduğunu belirtmektedirler. İsa'nın tanrı olamayacağını Yeni Ahit'ten delillerle ${ }^{66}$ ispat etmeye çalışırlar. Bu bağlamda onun, sadece bir insan ve babasının da Yusuf olduğunu dile getirirler. İsa'nın haça gerilmesini Yahudilere yükleyen pasajları öne çıkartan Hıristiyanlara karşı onlar da; 'o sizin tanrınız, bizler bir tanrıyı nasıl öldürebiliriz?' şeklinde ironik bir cevapla yanıtlamaya çalışırlar. ${ }^{67}$

Kadınlara ilişkin hususlarda da onların dikkat çekici uygulamaları bulunmaktadır. Örneğin Levililer Kitabı'nda geçtiği ${ }^{68}$ üzere eğer bir kadın regl döneminde ise onun dokunduğu her şey kirli olacağından kadının 7 gün diğer kişilerden izole edilmiş bir durumda kalması gerekir. Bu nedenle kan evi (ye dam bet) denilen bir yere çekilen kadın, eşinden ve etrafındakilerden uzak durur. Bu kulübenin etrafına bir işaret olarak taşlar dizilir ve genellikle bunlar, yerleşim alanının dışında bulunurlar. Yedinci günün sonunda kadın bir nehirde yıkanır ve evine döner. ${ }^{69}$ Yine Levililer Kitabı'na ${ }^{70}$ dayanarak eğer bir kadın erkek çocuk doğurursa 40 gün; kız çocuk doğurursa da 80 gün toplumdan uzak bir şekilde doğum evi (ye margam gogo) denilen kulübede kalır. ${ }^{71}$ Bu nedenle olsa gerek Etiyopya'da Falaşa'lara, attenkun yani 'bana dokunma' anlamında bir isimlendirme de yapılmaktadır. Bunun arkasında onların bu temizlik ile ilgili vurgu ve uygulamaları yatıyor olmalıdır. Ayrıca yukarıda

65 Pawlikowski, 'The Judaic Spirit of the Ethiopian Orthodox Church', s. 196.

66 Luka, 2:48. Meryem ve Yusuf'un İsa'yı araması ve kaygılanmaları, onun tanrı olamayacağına işaret olarak yorumlanmaktadır.

67 Salamon, The Hyena People, s. 87-96.

68 Levililer, 15:19.

69 Quirin, 'Caste and Class in Historical North-West Ethiopia, s. 210; Salamon, The Hyena People, s. 97-100; Weil, 'Ethiopian Jewish Women', s. 78.

70 Levililer, 12:1-6.

71 BenEzer, The Ethiopian Jewish Exodus, s. 17; Weil, 'Ethiopian Jewish Women', s. 78. 
açıklandığ rın, seküler bir toplumda (İsrail) bu tür uygulamaları da sorun haline gelmiştir. Toplumdan uzak bir yerde kalma gibi bir uygulama, İsrail'de evin bir köşesine çekilme ve ayrı odada oturma gibi bir pratiğe dönüşmüştür.

Kadınlara yönelik bahsi geçen uygulamalar, birçok Falaşa'nın İsrail'e gelmesiyle birtakım değişikliklere uğramak zorunda kalır. Yukarıda belirtildiği üzere Etiyopya'da olduğu gibi regl dönemindeki kadın artık yerleşim alanının dışında bir yere gitmeyip dairenin bir odasında kalmaktadır. Ayrıca Etiyopya'dayken buluğ çağına eren kızın hemen evlendirilmesi söz konusu iken İsrail'de 17 yaşından küçüklerin evlendirilmesinin yasal olmaması nedeniyle bu uygulama da artık işlememektedir. ${ }^{72}$

Yahudilerin diğer mezheplerinde olduğu üzere Falaşa'lar açısından da sünnet önemli bir ritüeldir. Erkek çocuklar, doğumunun ardından sekizinci günde annesinin bulunduğu ya margam gogo'da sünnet edilir. Sünnet işini yerine getirecek haham, kirlenmemek için kulübeden belirli bir uzaklıkta durup kulübeye dokunmaz. İbrahim ve diğer ataların sünnet olduğuna dair pasajlar ile On Emir okunduktan sonra kadına dokunmadan sünnet yerine getirilir. Böylece tamamlanan sünnetin kutlanması, ancak kadın 40 günlük kirlilik süresini bitirdikten sonra yapılır. ${ }^{73}$ İsrail'de sünnet, tam bir kutlama şeklinde icra edilirken; Etiyopya' da bu ritüel, toplumdan izole edilmiş margam gogo'da yapılır. Bu nedenle İsrail'e gelen Falaşa'lar, brit mila'nın sinagog'ta yapılmasına karşı çıkmış ve bu hususta anlaşmazlıklar yaşanmıştır. Çünkü sünnet aşamasındaki çocuk, kirli kabul edilip böyle bir kişinin sinagog'a nasıl getirildiği üzerinde tartışmalar yaşanmıştır.

Hayvan boğazlama ile ilgili hususlarda da sıkı sıkıya Tora'ya bağlı olan Falaşa'lar, diğer Yahudilerde olduğu üzere öncelikle hayvanın kesimi için çok keskin bıçak kullanırlar. Kesimden sonra kanın akması için hayvanı ağaca asarlar. ${ }^{74} \mathrm{Bu}$ hususları, Etiyopya Hıristiyanları garipsemektedirler.

\footnotetext{
72 Weil, 'Ethiopian Jewish Women', s. 79.

73 BenEzer, The Ethiopian Jewish Exodus, s. 22.

74 Salamon, The Hyena People, s. 100-101.
} 
Masgid ismini verdikleri sinagog, Etiyopya'daki Falaşa'ların köylerinin tepe noktasında bulunmaktadır. Genellikle yuvarlak biçimde yapılan masgidler, üç bölüme ayrılır. Kutsalın kutsalı olarak kabul edilen en içteki bölmeye sadece başhahamlar girer ve burada Orit ve diğer kutsal eşyalar bulunur. İkinci bölme de kendi arasında üçe ayrılır ve güney tarafta kadınlar, batı tarafta debtara denilen rahip yardımcıları ve kuzeyde de erkekler ibadetlerini yerine getirir. Üçüncü bölme ise altarı da içine alacak şekilde tüm sinagogu çevreleyen bir bölmedir. ${ }^{75}$

\section{Sonuç}

Etiyopya, animizmden Yahudiliğe, Hıristiyanlıktan İslam'a kadar birçok dini geleneği kendi içinde barındıran önemli yelerden biridir. Etiyopya' da kişinin en temelde hissettiği izlenim, sanki her şeyin fanus içinde dış etkilerden uzak bir şekilde korunduğudur. Bu hususta Yahudilik de 'en saf' haliyle burada rahatlıkla görülebilmektedir.

Birtakım dini ve siyasi amaçlar bağlamında farklı kökenlere dayandırılmaya çalışılan Falaşa'lara, değişik dönemlerde, toplum içindeki algılanmalarına binaen farklı isimler verilmiştir. Bu bağlamda kayla, buda, Beta İsrail vb. terimler, onların Etiyopya'da nasıl alg1landıklarına dair önemli işaretler taşımaktadır. Tarihi süreç içinde sürekli sürgün ile karşı karşıya kalan Yahudilerin akıbetini, Falaşa'lar da çok derinden yaşamış ve Etiyopya içinde de sürekli bir yerden bir yere göç etmek zorunda kalmışlardır.

Farklı operasyonlarla İsrail'e getirilen Falaşa'lar, bir taraftan büyük bir mutluluk duyarken öte yandan hem kültürel hem de dinî şok yaşamışlardır. İlk başta kendilerinin Yahudi olup olmadığı ile ilgili tartışmaların yapıldığını görmeleri üzerine büyük bir hayal kırıklığına uğrayan Falaşa'lar, aynı zamanda İsrail'deki modern hayatın zorunlulukları ile inançları arasında bir uzlaştırma yapmakta da zorlanmışlardır.

Kutsal Kitaba sıkı sıkıya bağlı olan Etiyopyalı Yahudiler, Kutsal Kitap sonrası oluşan Talmud ve Mişna gibi sözlü geleneklerden habersizdirler. Bu nedenle de dinin yaşanması hususunda diğer Yahudi gruplardan farklı uygulamalara sahiptirler. Manastır hayatı, günah itirafı ve kurban geleneğinin devam etmesi, bu hususta öne

75 BenEzer, The Ethiopian Jewish Exodus, s. 17. 
çıkan örneklerdir. Yine Hanuka ve Purim gibi bayramlar, Kutsal Kitabın yazımından sonra ortaya çıktığı için Falaşa'lar tarafından bilinmezler.

Kendi dininden olmayan biriyle oturup kalkmanın yasak olduğu şeklindeki uygulamayı, Falaşa'lar o kadar ileri götürmüşlerdir ki onlara attenkun yani 'bana dokunma' şeklinde bir isim verilmiştir. Yine kadının regl durumu ve çocuk doğurması sonrası uygulamaları da oldukça ilgi çekicidir.

Etiyopya' da bulunduğumuz süre içinde bir Falaşa ile mülakat yapma şansına sahip olmuştuk. Kendi dininden olmayan biriyle konuşma hususunda sıkıntı yaşamamış ve hatta oturup beraber yemek yemiştik. Bu, en azından o kişinin dini emri yorumlamada nereye geldiğine dair önemli bir işarettir. Konuşmamız esnasında ona, 'Addis Ababa'daki bir sinagog'da yapılacak Şabat ayinine katılmamızın mümkün olup olmadığını' sorduğumuzda 'bunun için İsrail'deki dini yetkililerden izin almamızın' gerektiğini söylemesi ise hayli ilgi çekiciydi. Bu husus, İsrail ile Etiyopyalı Yahudilerin hali hazırdaki yakınlıklarına önemli bir işaret olarak görülebilir. Aynı zamanda Falaşa'ların, İsrail özlemini göstermesi açısından da dikkat çekicidir.

\section{Kaynakça}

Charles Singer ve Woldah Haimanot, 'The Falashas', The Jewish Quarterly Review, 17.1, (Ekim) 1904.

Christine Chaillot, The Ethiopian Orthodox Tewahedo Church Tradition, Paris, 2002.

Count Gleichen, With the Mission to Menelik, London, 1898.

D.H. Shinn ve T.P. Ofcansky, Historical Dictionary of Ethiopia, Maryland, 2004.

Daniel Friedman ve Ulysses Santamaria, 'Identity and Change: The Example of Falashas, Between Assimilation in Ethiopia and Integration in Israel, Dialectical Anthropology, 15.1, 1990.

De Lacy O'leary, The Ethiopian Church, London, 1936.

Donald Crummey, 'Church and Nation The Ethiopian Orthodox Tawahedo Church', The Cambridge History of Christianity, (ed. Michael Angold), V, Cambridge, 2006.

Dursun Ali Aykıt, Hıristiyanlı̆̆ın Öncüsü Olarak İskenderiyeli Philo, İstanbul, 2010.

E. Ullendorff, 'Note on the Introduction of Christianity into Ethiopia', Africa: Journal of the International African Institute, 19.1, (Ocak) 1949. 
Edward Ullendorff, 'Hebraic-Jewish Elements in Abyssinian (Monophysite) Christianity', Journal of Semitic Studies, 1.3, 1956

Edward Ullendorff, 'Hebraic-Jewish Elements in Abyssinian Monophysite Christianity', The Journal of Semitic Studies, 1.3, 1956

Flavius Josephus, Jewish Antiquities, (terc. J. Thackerapy ve R. Malcus), VIII, (Loeb Classical Library), London, 1950.

Gadi BenEzer, The Ethiopian Jewish Exodus, New York, 2002.

Gerard Lucetto ve Pierrre Smets, 'Origins of Falasha Jews Studied by Haplotypes of the Y Chromosome', Human Biology, 71.6, (Aralık) 1999.

Hagar Salamon, The Hyena People: Ethiopian Jews in Christian Ethiopia Contraversions, California, 1999.

http://www.knesset.gov.il/lexicon/eng/sigd_eng.htm (02.10.2013)

J. M. Harden, An Introduction to Ethiopic Christian Literature, London, 1926.

James Quirin, 'Caste and Class in Historical North-West Ethiopia: The Beta Israel (Falasha) and Kemant 1300-1900', The Journal of African History, 39.2, 1998.

James Quirin, 'Oral Tradations as Historical Sources in Ethiopia: The Case of the Beta Israel (Falasha)', History in Africa, 20, 1993.

James Quirin, 'The Process of Caste Formation in Ethiopia: A Study of the Beta Israel (Felasha) 1270-1868', The International Journal of African Historical Studies, 12.2, 1979.

Jean Doresse, Ethiopia, (terc.: E. Coult), London, 1959.

John Baur, 2000 Years of Christianity in Africa, Kenya, 1998.

John T. Pawlikowski, 'The Judaic Spirit of the Ethiopian Orthodox Church: A Case Study in Religious Acculturation', Journal of Religion in Africa, 4.3, 1971-1972.

Kay Kaufman Shelemay, 'Historical Ethnomusicology: Reconstructing Falasha Liturgical History', Ethnomusicology, 24.2, 1980.

Kazım Karabekir, İtalya- Habeş, İstanbul, 2001.

Komisyon, The Church of Ethiopia a Panorama of History and Spiritual Life, Addis Ababa, 1997.

Lule Melaku, History of The Ethiopian Orthodox Tewahedo Church II-III, Addis Ababa, 2010.

Marilyn E. Heldman, 'Architectural Symbolism, Sacred Geography and the Ethiopian Church', Journal of Religion in Africa, 22, (Ağustos) 1992.

Max Wurmbrand, 'Remarks on the Text of the Falasha Death of Moses', Bulletin of the School of Oriental and African Studies, 25. 1-3, 1962.

Mitchell G. Bard, From Tragedy to Triumph: The Politics Behind the Rescue of Ethiopian Jewry, Connecticut, 2002.

Mordecai Roshwald, 'Marginal Jewish Sects in Israel (II)', International Journal of Middle East Studies, 4.3, (Temmuz) 1973. 
Mustafa Fayda, İslamiyetin Güney Arabistan'a Yayılışı, Ankara, 1982.

Özcan Hıdır, Yahudi Kültürü ve Hadisler, İstanbul, 2006.

Richard Pankhurst, 'The Falashas or Judaic Ethiopians in Their Christian Ethiopian Setting', African Affairs, 91.365, (Ekim) 1992.

Samuel Gobat, Journal of a Three Years' Residence in Abyssinia, (2. ed.), London, 1850.

Shalva Weil, 'Ethiopian Jewish Women: Trends and Transformation in the Context of Transnational Change', Nashim: A Journal of Jewish Women's Studies and Gender Issues, 8, 2004.

Stephen Spector, Operation Solomon: The Daring Rescue of the Ethiopian Jews, New York, 2005.

Steven Kaplan, 'The Beta Israel (Falasha) Encounter with Protestant Missionaries: 1860-1905', Jewish Social Studies, 49.1, (Kış) 1987.

Steven Kaplan, The Beta Israel (Falasha) in Ethiopia: From Earliest Times to the Twentieth Century, New York, 1995.

Steven Kaplan, The Monastic Holy Man and the Christianization of Early Solomonic Ethiopia, Almanya, 1984.

The Kebra Nagast, (terc.: E.A.W. Budge), Forgetten Books, 2010.

Tudor Parfitt ve Emanuela Trevisan Semi (ed.), Jews of Ethiopia, London, 2005.

Ulysses Santamaria, 'Ethiopian Jews in Israel', Dialectical Anthropology, 18.34, 1993. 


\section{MILEL VE NIHAL}

inanç, kültür ve mitoloji araştırmaları dergisi

Cilt/Volume: 11 Sayı/Number: 2 Temmuz - Aralık / July - December 2014

ISSN: 1304-5482

Bu dergi uluslararası EBSCO HOST Research Databases veri indeksi ve

TÜBITAK-ULAKBİM Sosyal ve Beşeri Bilimler Veri Tabanı tarafından taranmaktadır.

\section{Sahibi / Owner}

Milel ve Nihal Eğitim, Kültür ve Düşünce Platformu Derneği adına Şinasi Gündüz

$$
\begin{aligned}
& \text { Yazı İşleri Sorumlusu / Legal Representative } \\
& \text { Yasin Aktay }
\end{aligned}
$$

Editör / Editor

Şinasi Gündüz

Editör Yrd. / Co-Editor

Cengiz Batuk

Hakan Olgun

\section{Yayın Kurulu/ Editorial Board*}

Alpaslan Açıkgenç, Ayaz Akkoyun, Yasin Aktay, Mahmut Aydın,

Cengiz Batuk, Şinasi Gündüz, İbrahim Kayan, Hakan Olgun, Necdet Subaşı,

\section{Burhanettin Tatar}

\section{Danışma Kurulu/Advisory Board*}

Baki Adam (Prof. Dr., AÜ); Mohd. Mumtaz Ali (Prof. International Islamic U. Malezya); Adnan Aslan (Prof.Dr., Süleyman Şah Ü.); Kemal Ataman (Doç.Dr., Uludağ Ü.); Mehmet Akif Aydın (Prof. Dr., Marmara Ü.); Yılmaz Can (Prof. Dr., OMÜ); Ahmet Çakır (Doç. Dr., OMÜ); Mehmet Çelik

(Prof. Dr., Celal Bayar Ü.); Waleck S. Dalpour (Prof. University of Maine at Farmington); İsmail

Engin (Dr., Berlin); Cemalettin Erdemci (Prof.Dr. YYÜ); Tahsin Görgün (Prof.Dr., 29

Mayıs Ü.) Ahmet Güç (Prof.Dr., Uludağ Ü.); Recep Gün (Doç. Dr., OMÜ); Ö. Faruk Harman

(Prof.Dr., Mar.Ü.); Erica C.D. Hunter (Dr., Cambridge U.); Mehmet Katar (Prof. Dr., A.Ü.);

Mahmut Kaya (Prof. Dr., İ.Ü.); Sadık Kılıç (Prof.Dr., Atatürk Ü.); Şevket Kotan (Y.Doç.Dr., İ.Ü.); İlhan Kutluer (Prof.Dr., Mar. Ü.); George F. McLean (Prof. Catholic Univ., Washington DC); Ahmet Yaşar Ocak (Prof. Dr., Hacettepe Ü.); Jon Oplinger (Prof. University of Maine at Farmington); Ömer Özsoy (Prof.Dr., Frankfurt U.); Roselie Helena de Souza Pereira (Mestre em

Filofia-USP; UNICAMP Brasil); Ekrem Sarıkçıŏlu (Prof.Dr., SDÜ); Hüseyin Sarıoğlu (Prof.Dr.,

İÜ); Bobby S. Sayyid (Dr. Leeds U.); Mustafa Sinanoğlu (Prof.Dr., 29 Mayıs Ü.); Mahfuz Söylemez

(Prof.Dr. IÜ); Necdet Subaşı (Y.Doç.Dr., DİB); Bülent Şenay (Prof.Dr., UÜ); İsmail Taşpınar

(Prof.Dr. Mar.Ü.); C. Sadık Yaran (Prof.Dr., OMÜ); Ali Murat Yel (Prof.Dr., Fatih Ü.); Hüseyin Yılmaz (Doç.Dr., YYÜ); Ali İhsan Yitik (Prof. Dr., DEÜ)

* Soyadına göre alfabetik sıra / In alphabetical order

\section{Kapak ve Sayfa Tasarımı / Cover \& Page Design} İnan Avc1

Baskı / Publication

Ladin Ofset - İstanbul, Haziran 2015

2.Mat. Sit. 3 NB 15 Topkapi İstanbul / İsmail Tüz 02125012418

Yönetim Yeri / Administration Place

Milel ve Nihal Eğitim, Kültür ve Düşünce Platformu Derneği

Fevzipaşa Cad. Şehit Mehmet Sarper Alus Sok. No: 5, K.: 3, Tel: (0212) 5339731 Fatih/İstanbul www.milelvenihal.org e-posta: dergi@milelvenihal.org

Milel ve Nihal yılda iki sayı olarak altı ayda bir yayımlanan uluslararası hakemli bir dergidir. Milel ve Nihal' de yayımlanan yazıların bilimsel ve hukuki sorumluluğu yazarlarına aittir. Yayım dili Türkçe ve İngilizce'dir. Yayımlanan yazıların bütün yayın hakları Milel ve Nihal'e ait olup, yayıncının izni olmadan kısmen veya tamamen basılamaz, çoğaltılamaz ve elektronik ortama taşınamaz. Yazıların yayımlanıp yayımlanmamasından yayin kurulu sorumludur. 


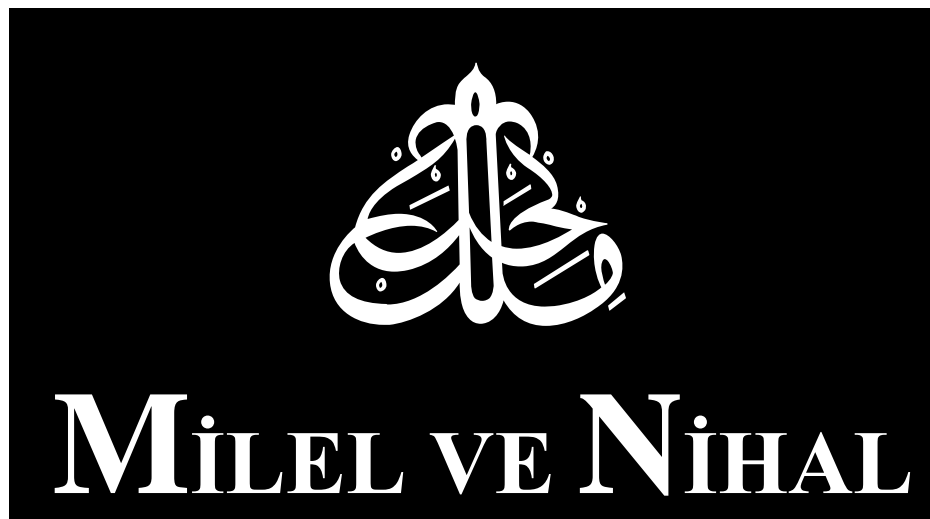

inanç, kültür ve mitoloji araştırmaları derogisi

ISSN: 1304-5482

Cilt/Volume: 11 Sayı/Number: 2

Temmuz - Aralık / J uly - December 2014 


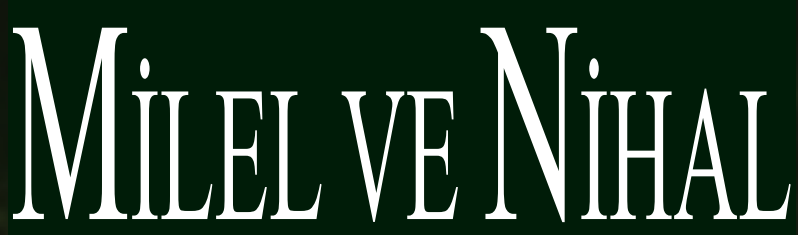

inanç, kültür ve mitoloji araştırmaları dergisi

ISSN 1304-5482

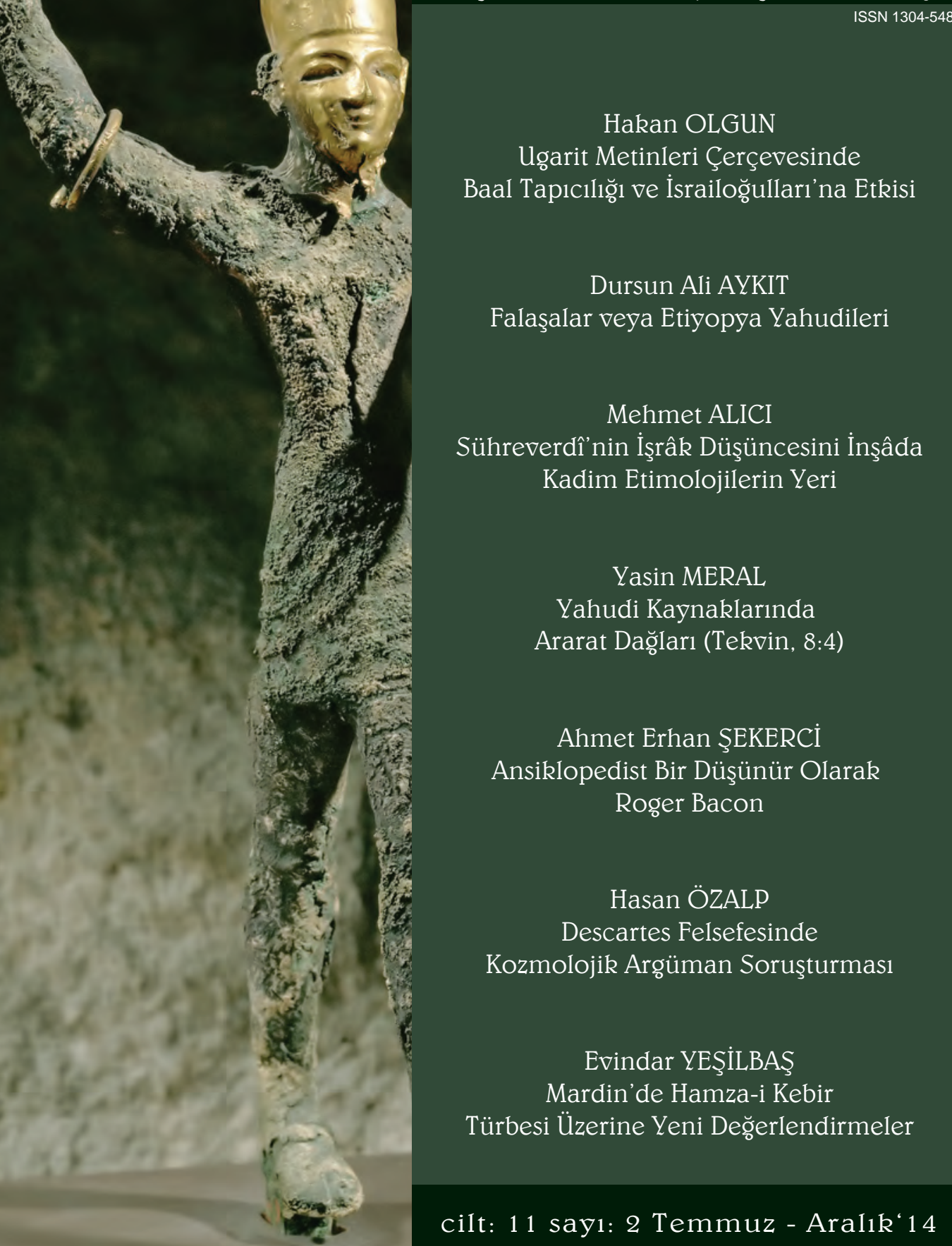

